\title{
THE TRANSMISSION AND SPREADING ROUTES OF AUJESZKY'S DISEASE IN SWINE POPULATION
}

\author{
J. Prodanov-Radulović, R. Došen, I. Pušić, I. Stojanov, D. Lupulović, \\ R. Ratajac
}

Scientific Veterinary Institute „Novi Sad“, Rumenački put 20, 21000 Novi Sad, Republic of Serbia Corresponding author: jasna@niv.ns.ac.rs

Original scientific paper

\begin{abstract}
Aujeszky's disease (MA) is an infectious viral disease, caused by suid alpha herpes virus 1 , which displays a very broad host range, except humans and primates. Pigs are the only animal species that can survive the infection with the MA virus, which accounts for its ability to be latently infected. Although pigs are considered a natural host and the main reservoar of the virus, the spreading and transmission mechanism cannot be always detected. The aim of the paper was to evaluate the routes of transmission and spread of MA virus in the swine population with different immunological stutus i.e. depending on the vaccinal status. The material for this research consisted of the samples from four swine farms, with health disorders i.e. clinical signs suggesting MA disease. The applied research methods included: epidemiological and clinical evaluation, pathomorphological examination, virology testing of tissues originating from the dead animals and serological testing in order to evaluate the specific antibodies against MA. The obtained results indicate that purchasing breeding animals with different or unknown health status regarding MA, represents the main route of transmission and spreading of the infection. Besides vaccination, which represents one of the measure in MA eradication, it is necessary to apply strict trade control and checking the health status of herds from where breeding animals are purchased.
\end{abstract}

Key words: Aujeszky's disease of swine, transmission routes, vaccination

\section{Introduction}

Aujeszky's disease (Morbus Aujeszky, MA) is an infectious viral disease, caused by suid alpha herpes virus 1 , which displays a very broad host range, except humans and primates (Allepuz et al., 2009). Pigs are the only animal species that can survive the infection with MA virus, which accounts for its ability to be subclinically (latently) infected (Newbya et al., 2002; Martinez-López et al., 2009). Although pigs are considered a natural host and the main reservoar of the virus, the spreading and transmission mechanism cannot be always detected. It is considered 
that the introduction of subclinically infected pigs (carriers) in a herd, represents the main route of disease transmission (Carr, 2006; Prodanov et al., 2007). Additional stress factors (transportation, farrowing) may reactivate latent infection and shedding of the virulent virus can occur (Allepuz et al., 2009). MA virus is shed in nasal and oral secretions and is aerosolized in droplets, which are moved rapidly by airflow to susceptible swine within and adjacent to shared airspaces; the virus is also transmitted transplacentally and via vaginal mucosa, semen and milk. The outbreak ends with essentially every convalescent animal permanently latently infected (Kluge et al., 1999).

Aujeszky's disease affects many countries and regions in the world, causing important economic losses, mainly due to international trade restrictions (Carr, 2006). Many European countries have established MA eradication programs, with the objective of initially controlling and finally eradicating the disease. However, the risk of moving MA-infected animals into free or low prevalence areas remains an important problem for the control and eradication of MA (Martinez-López et al., 2009). Endemic disease is a major problem in spite of vaccination, because ultimate control is through the elimination of the latent carriers (Carr, 2006; Pušić et al., 2009).

The aim of this paper was to evaluate the routes of transmission and spread of MA virus in the swine population with different immunological stutus i.e. depending on the vaccinal status.

\section{Materials and Methods}

The material for this research consisted of the samples from four swine farms, where health disorders i.e. clinical signs suggesting MA disease, were detected. The applied research methods included: epidemiological and clinical evaluation, pathomorphological examination, laboratory virology testing (viral isolation on the susceptible cell culture, PK-15) of tissues originating from the dead animals. Also, serological testing by serum neutralization test (SNT) on the sera samples in order to evaluate the specific antibodies against MA was carried out.

\section{Results and Discussion}

In the first examined farm anamnestically, the health disorders in sows and in their litters were observed. By epidemiological investigation it was discovered that on the swine farm in total 50 new sows had been introduced 2 months ago. Serologically, in 6 sows the presence of specific antibodies against MA was detected (titar 1:16 do 1:64). However, despite the fact that these animals were serologically positive, the origin of that immunological status from the aspect of MA remained unknown: vaccination or infection. From other hand, the evaluated swine farm 8 years before stoped with the imunoprophylaxisis against MA. By clinical examination in sows the signs of inapetence, mild apathy and agalactiae 
were observed. In suckling piglets the sings of severe distrurbance of the central nervous system (CNS) were clinically detected (wide open eyes, paddling, trembling, convulsions, ataxia, paresis and paralysis, opistotonus, epileptiform-like seizures). In some cases the whole litter of piglets died within 48 hours. Clinically the fatteners also become anorectic, listless and apathic. The pathomorphological changes that were detected in dead sucklings indicated the lesions characteristic for MA infection: diphteroid and necrotic tonsilitis, swollen and occasionally hemorrhagic lymph nodes, focal necrosis on the liver and spleen in the form of yellow-white foci size 2-3 mm scattered, paresis of urinary blader, haemorrhages (petechiae) on the cortex of the kidneys, bleeding on the meninges, oedema and haemorrhages (petechiae) on the brain tissue. Applying viral isolation on the susceptible cell culture, from tissues from dead piglets MA virus was isolated. Applying additional serological testing of 6 newly introduced animals, the rise of titar of specific antibodies against MA virus was detected 2 months later after their purchase. The connection between newly purchased breeding animals with the outbreak of viral infection of swine MA was established.

Before purchasing breeding animals, the quarantine measures need to be taken (Došen et el., 2002). However, during quarantine, latently infected or subclinical infectious pigs may not be detected. Even if MA-infected pig shows the signs of the disease during quarantine, these signs may be unspecific (respiratory problems, fever, anorexia, loss weight) and not associated with MA (Prodanov et al., 2007). The risk of MA introduction via breeder pigs was shown to be nearly 14 times higher when quarantine vs. serology was the chosen control. Serological monitoring was shown to be successful in detecting infectious animals (MartinezLópez et al., 2009). The primary means of transmission of the MA virus among swine herds is thought to be by direct contact between infected and susceptible pigs because of movement of infected animals. Indirect contacts by vehicles, equipment, personnel, feed or artificial insemination can also spread the virus among herds. The virus may be transmitted among swine herds by aerosol suspensions of the virus (Allepuz et al., 2009; Kluge et al., 1999).

On the other examined farm it was discovered by anamenesis that 80 gilts were purchased. From epizootiological standpoint it was detected that the seller had two farms: one where vaccination against MA was carried out, and the other where this vaccination was not performed. The purchaser chose gilts from both farms, so unvaccinated and vaccinated gilts were deliverd to the same farm. The problem rose 2 weeks later in the litter of unvaccinated sows, with the sucklings: tremor, excessive salivation, skin cyanosis, ataxia, paddling, lack of coordination, walking in circles, yellowish diarrhoea. By pathomorphological examination in dead sucklings (10 animals) changes characteristic for MA were detected: focal areas of necrosis on the liver and spleen, paralysis of urinary blader, urin retency, bleeding on the meninges. Applying virology testing on the susceptible cell culture, from tissues of dead piglets MA virus was isolated.

Animal purchase is considered an important infection source. It was demonstrated that MA virus can be latently present in apparently normal animals 
without showing any clinical signs (Prodanov et al., 2007; Pušić et al., 2009). It is considered that MA infection is present in the most swine farms in the Republic of Serbia (Došen et el., 2002). The results published by Pušić et al. (2009) suggest that swine population in Vojvodina province is enzootically infected with MA virus. The vaccinated animals do not suffer from the symptoms of the disease, but they may contract a field infection, excrete live virus and therefore become cariers (Carr, 2006). The third examined case refers to the pig farm, the capacity 2500 sows and production capacity 40,000 fatteners per year. The health issue was established at weaning of piglets with clinical signs of respiratory illnesses and CNS diseases (dispnoea, coughing, paddling, trembling, convulsions, egzophtalmia). Epizootiological analysis showed that the farm performs immunoprophylaxis against MA, and the first vaccination of piglets is 10 days before weaning. Serological testing has shown a large variety of specific antibody values against MA (antibody titer of 1:4 to 1:128). From tissue samples of dead piglets in cell culture MA virus was isolated.

In addition to CNS dysfunction, MA virus can play a role in pathogenesis of respiratory syndromes. In the case of inadequate immunoprophylaxis against MA, the disease occurs primarily in weaning piglets (Dosen et al., 2002). Vaccines must be used in sows, in order to give protection to the young piglets via the colostrum (Carr, 2006). One of the main limitations of the imunnization of neonates from vaccinated or previously infected mothers is the interference with maternally derived antibodies (MDA). The half-life of MDA that pigs receive in the colostrum of MA-immune sows is approximately 18 days (Kluge et al., 1999). The aim of the vaccination programme is to create a good level of immunization in sows and uniform level of protection in the piglets during the first weeks of their life (Casal et al., 2004). There is a concern that modified live vaccines (MLV), after vaccination may revert back towards virulence during replication in the host (Newbya et al., 2002). In such cases, it is possible that the vaccinal virus circulates on farms immunising pigs, although the presence of a field strain of low virulence should not be excluded (Pušić et al., 2009).

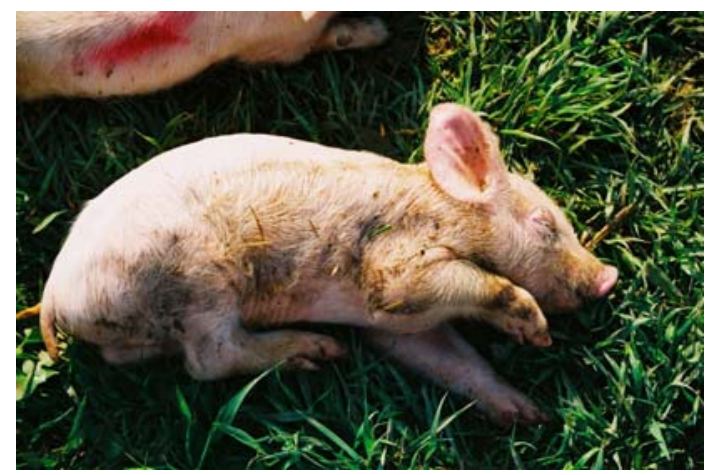

Picture 1. Neurvous clinical signs in suckling piglet 
Last investigated case relates to transmission of MA infection from large industrial to small pig farm. Medical history showed that the farmer owned 25 sows and a few days before he had bought 10 gilts that had not been vaccinated against MA. In addition, the farm has two boars that were bought 3-4 years ago from a large farm performing vaccination against MA. Clinically, the problem was found in suckling piglets: aphonia, recumbency, paddling, egzophtalmia, excessive salivation, seizures and death. Gross pathomorphological examination (11 corpses) determined diphteroid-necrotizing changes of the tonsils, bladder paralysis, focal necrosis of the liver and spleen, bleeding of the brain tissue, particularly in the area of the cerebellum. From tissue samples of dead pigs virus MA was isolated.

MA virus is highly neurotropic virus, and after the primary entrance to the host the virus replicates in the nasopharyngeal mucosa, tonsilis and the olfactory epithelia. The virus invades the CNS through the nerve ends in the tonsils and the upper respiratory tract. Highly virulent strains produce a nonsuppurative meningoencephalitis that causes fatal disease in piglets, with nervous clinical signs (Martinez-López et al., 2009). A primary outbreak of MA in a naive immunologically unprotected herd can be a devastating event, with spread through the entire herd within 1 week and ending with more than $90 \%$ of suckling pigs dead, nursery pigs stunted in their growth, and with respiratory disease in older hogs and abortions in sows (Carr, 2006). Inapparent infections rarely occur when MA virus is introduced into a herd for the first time where neonatal pigs are present, because pigs of this age are highly susceptible.

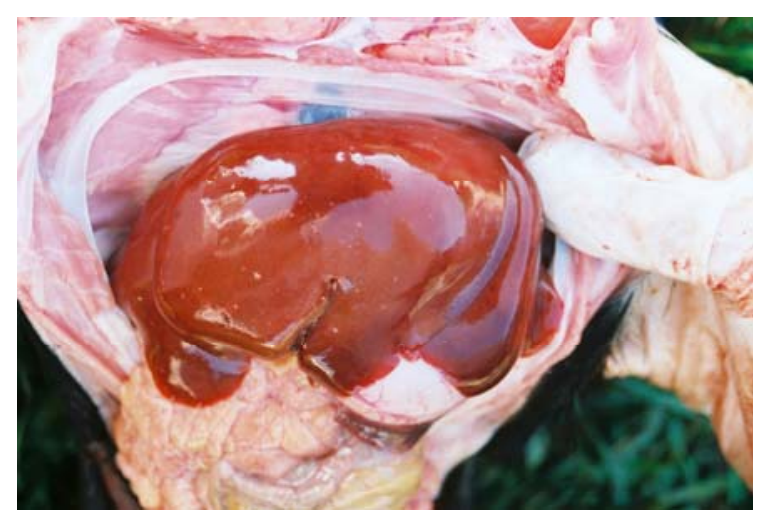

Picture 2. Liver with multiple small foci areas of necrosis

Described lesions i. e. herpetic and splenic yellow-white foci of necrosis are most frequently seen in young pigs that lack passive immunity (Kluge et al., 1999). The control of the disease in endemic countries is based on compulsory vaccination with MLV of the entire swine population (Casal et al., 2004). Currently, in Serbia healthy animals are immunized with MLV to minimise clinical disease and death loss. Vaccination alone is unlikely to eradicate the disease due to the problem of latent carriers (Carr, 2006; Newbya et al., 2002). However, herd- 
specific risk factors such as biosecurity measures, vaccination schemes or the health status of the purchased pigs might be much more related to the success of the MA eradication programme (Allepuz et al., 2009).

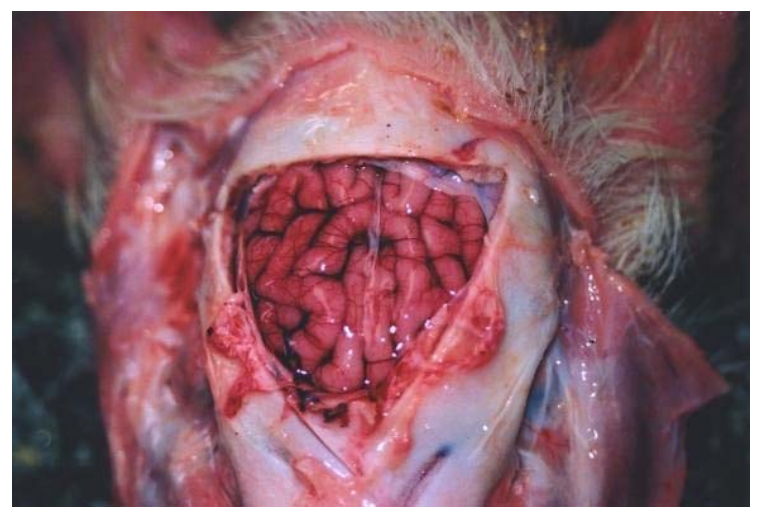

Picture 3. Haemorrhages on the meninges and the brain tissue

On the evaluated farms the biosecurity measures (quarantin, serological examination) were not always applyed because there is no legal obligation for internal trade in Serbia. In many industrialized countries, efforts are made to eradicate MA. To reach this goal, the development and approval of a glycoprotein$\mathrm{E}$ ( $\mathrm{gE}$ ) deleted vaccine was the decisive break-through, as this vaccine made it possible for the first time to distinguish infected from vaccinated pigs. However, even under vaccination virus replication occur, depending on the duration and design of the vacination programme and the existance of infected herds in the surrounding area (Müller et al., 2003).

\section{Conclusion}

The obtained results indicate that purchasing of breeding animals, with different or unknown health status regarding MA, represents the main route of transmission and spreading of the infection. The outbreak of Aujeszky's disease on the swine farm, where immunoprophylaxis was not carried out and purchasing the breeding animals where vaccination against MA was applied, may lead to devastating consequences. The reason for this is the phenomenon of latent infection with reactivation and sheding of the virulent virus (Prodanov et al., 2007; Pušić et al., 2009). Besides vaccination, which represents one of the measure in MA eradication, it is necessary to apply strict trade control and checking the health status of herds from where breeding animals are purchased. Therefore, additional biosecurity measures to support vaccination programmes needed to be taken, including quarantine, serological monitoring, consequent managemant and movement restrictions. The establishment of national eradication programme is 
essential basis for controlling MA in Serbia. Vaccination against MA should be limited in space and time, and, in the end, it should be replaced by a rigorous staming out policy in order to accelerate eradication and to obtain an MA-free status as soon as possible. In the future, the establishment of a national eradication program could be an essential step towards controlling and finally eradicating MA in the country.

\title{
Acknowledegment
}

Research was financed by the Ministry of Education and Science, Republic of Serbia, project TR 31084 .

\section{Putevi prenošenja i širenja virusa aujeskijeve bolesti u populaciji svinja}

\author{
J. Prodanov-Radulović, R. Došen, I. Pušić, I. Stojanov, D. Lupulović, R. Ratajac
}

\section{Rezime}

Aujeskijeva bolest (MA) je infektivno virusno oboljenje, čiji je uzročnik svinjski alfaherpes virus 1 , koji inficira široki opseg domaćina izuzev ljudi i primata. Svinje predstavljaju jedinu životinjsku vrstu koja može preživeti infekciju sa virusom Aujeskijeve bolesti (MA), nakon čega se uspostavlja latentna infekcija. Iako se svinje smatraju prirodnim domaćinom i glavnim rezervoarom virusa, mehanizam širenja i prenošenja infekcije nije uvek moguće utvrditi. Cilj rada je bio ispitivanje puteva prenošenja i širenja virusa MA u populaciji svinja različitog imunološkog statusa sa aspekta primene vakcinacije. Materijal za ispitivanje je obuhvatao 4 farme svinja na kojima su registrovani zdravstveni problemi, koji su ukazivali na MA. U okviru primenjenih metoda obavljena su epizootiološka i klinička ispitivanja, patomorfološki pregled uginulih jedinki, virusološka ispitivanja (izolacija virusa) i serološka ispitivanja u cilju ustanovljavanja prisustva specifičnih antitela protiv MA. Postignuti rezultati ispitivanja ukazuju da kupovina priplodnog materijala iz izvora koji ima drugačiji ili nepoznat zdravstveni status u pogledu MA predstavlja glavni put prenošenja i širenja infekcije.

\section{References}

ALLEPUZ A., SEAZ M., SOLYMOSI N., NAPP S., CASAL J. (2009): The role of spatial factors in the success of an Aujeszky's disease eradication programme in a high pig density area (Northeast Spain, 2003-2007). Prev Vet Med, 91, 153-160. 
CASAL L., PLANASDEMUNT LL., VARO J. A., MARTIN M. (2004): The use of different vaccination schedules for sows to protect piglets against Aujeszky's. Disease. J. Vet. Med. B, 51, 8-11.

CARR J. (2006): Aujeszky's disease (Pseudorabies). In: KYRIAZAKIS AND WHITTEMORE C.T. (eds), Whittemore's Science and Practice of Pig Production, 3rd edition, Blackewell Publishing, 7, 311-312.

DOŠEN R., GAGRČIN M., PRODANOV JASNA, LALIĆ M. (2002): Neki epizootiološki momenti kod Aujeskijeve bolesti. Savremena poljoprivreda, 51, 3-4, 269-271.

KLUGE J.P., BERAN G.W., HILL H.T., PLATT K.B. (1999): Pseudorabies (Aujeszky's Disease). In: STRAW B.E., D'ALLAIRE S., MENGELING W.L., TAYLOR D.J.(eds), Disease of swine. 8th edition., Blackwell Science, 19, 233-246.

NEWBYA T.J., CARTERB D.P., YOONC K.J., JACKWOODD M.W., HAWKINSE P.A. (2002): Assessment of replication and virulence of attenuated Pseudorabies virus in Swine. J. Vet. Sci., 3, 2, 61-66.

MARTINEZ-LÓPEZ B., CARPENTER T.E., SÁNCEZ-VIZCAINO J.M. (2009): Risk assessment and cost-effectiveness analysis of Aujeszky's disease virus introduction through breeding and fattening pig movements into Spain. Prev Vet Med, 90,10-16.

MÜLLER T., BÄTZA H-J., SCHLÜTER H., CONRATHS F. J., METTENLEITER T. C. (2003): Eradication of Aujeszky's Disease in Germany. J. Vet. Med., B50, 207-213

PRODANOV JASNA, DOŠEN R., PETROVIĆ T., STOJANOV I, PUŠIĆ I. (2007): Aujeskijeva bolest prasadi na sisi. Zbornik radova IX regionalno savetovanje iz kliničke patologije i terapije životinja, Palić-Beograd, Fakultet Veterinarske medicine.

PUŠIĆ I., ĐURIČIĆ B., DOŠEN R., PRODANOV J., PETROVIĆ T., BURSAĆ V., UROŠEVIĆ M. (2009): Evaluation of the presence of specific antibodies against Morbus Aujeszky virus in unvaccinated swine in Vojvodina province. Biothechnology in Animal Husbandry, 25, 5-6, 887-893. 